\title{
Determinants of SME brand adaptation in global marketing
}

\begin{abstract}
Previous studies have focused on the degree of standardization or adaptation and to a lesser extent on the determinants of adaptation. This paper advances the literature in four respects. Firstly, we are able to evaluate the relative importance of internal (commitment; experience) versus external (culture, economic) determinants of adaptation. Secondly, we have examined several firm size categories, so we can evaluate how the relative roles of internal and external factors vary by firm size. Thirdly, rather than treat adaptation as one of adjusting one or more of the four-Ps, we use a more holistic concept of adaptation, namely brand adaptation, and which subsumes marketing mix adaptation. A scale has been developed to capture this holistic concept. Fourthly, we have developed a new culture scale, one based on the perceptions of SME businesses, using domestic operations as a benchmark.
\end{abstract}

\section{Introduction}

SMEs unavoidably face strategic choices of standardisation or adaptation of their marketing in their international marketing activities. Increasingly firms have to make these decisions across several countries, forcing a global perspective on the matter. Global marketing is inherently a holistic concept, so this makes it useful to consider global branding as a relevant framework to discuss this decision. Branding has often been considered in the context of larger firms, but a recent study has shown that it is also useful and applicable SMEs in the domestic context (Wong \& Merrilees, 2005). There is therefore the potential to apply a branding framework to SME global marketing which is the approach taken in the current study. 
The paper extends the standardisation versus adaptation debate from marketing mix adaptation to brand adaptation. Brand adaptation subsumes marketing mix adaptation, but has a more central focus on the market position and brand identity. More specifically, the paper empirically tests the determinants of international brand adaptation of a sample of nearly 300 Australian SME firms. We are especially mindful of competing hypotheses of what drives adaptation, in particular external (culture and economic) versus internal (experience and commitment of resources) factors. The determinants are further explored by disaggregating firm size into four groups in order to examine whether the mix of determinants varies by firm size. Large firms (greater than 500 employees) have not been included in this paper, but we are to distinguish between micro, small and medium-sized firms, something that the literature appears not to have done. Moreover, this paper puts forward the measurements of two new global marketing constructs, brand repositioning and cultural differences.

\section{Literature Review}

\section{Standardisation or adaptation}

The issue of standardisation versus adaptation in international marketing activities has been prominent in the international literature following the publication of Levitt's (1983) article on the globalisation of markets. He argued that there has been an increase in the similarity of markets across the globe due to much improved communications, travel and the emergence of demographically similar segments in different countries. This suggestion is based on a view that the world market is made up of a number of standardised markets rather than a large number of customised 
markets. Firms can serve the world market in a more economical manner by means of large-scale production. Even though the original starting point of Levitt's article was concerned with global products rather than global brands, it soon activated a great interest in global branding, particularly in the advertising community (Fisher, 1984).

\section{Advantages of standardization}

The arguments in favour of standardisation of marketing program are centered on two main aspects (Theodosiou \& Katsikeas, 2001). Firstly, a global mindset and developments in the international business environment add pressure for standardisation. Secondly, there are cost advantages of pursuing a strategy of international marketing program standardisation. The standardisation of products and marketing strategy is a viable method to furnish cross-subsidisation due to the fact that firms can get advantage of global brand and global channels domination (Zou, Andrus, \& Norvell, 1997). The advocates of standardization further suggest that world markets are becoming homogeneous due to the rapid advancement in transportation and communication technologies (Levitt, 1983; Ohmae, 1985). Cultural convergence will proceed at an accelerated rate due to the proliferation of television satellites and increased cable penetration that will enable viewers' access to international issues and cultures (Wind, 1986). Homogenization of consumer tastes provides firms with opportunities to achieve cost savings by means of economies of scales in production, marketing and other activities through standardization (O'Donnell \& Jeong, 2000). Another argument for standardisation includes the need of international firms to serve their multinational customers (Douglas \& Wind, 1987). This central argument is that when customers go global, it is better off for firms to follow their customers to go global in order to benefit the economy of scale. 
Cost savings can be achieved not only from production, but also in research and development, distribution and promotion (Douglas \& Wind, 1987; Onkvisit \& Shaw, 1989). A standardization approach might contribute to a consistently strong brand image across the countries (Hallibuton \& Hunerberg, 1993). Some empirical studies supported this view, having found high levels of brand name standardization (Rosen, Boddewyn, \& Louis, 1989; Sandler \& Shani, 1992; Still \& Hill, 1984). However, another study has found a contradictory result that the vast majority of Fortune-500 firms localise their brand names by using the strategy of transliteration of the brand name for the Chinese market (Francis, Lam, \& Walls, 2002). The standardisation approach of international marketing strategy emphasizes the financial benefits.

\section{Advantages of adaptation}

Proponents of adaptation argue that world markets are not getting homogeneous, as there are differences in physical environment, legal requirements, cultures, economic development, infrastructure among national markets (Boddewyn, Soehl, \& Picard, 1986; Cavusgil, Zou, \& Naidu, 1993; Hill \& Still, 1984; Wind, 1986; Zou \& Cavusgil, 1996). It is argued that firms rarely desire, if it were possible, total standardization of their marketing activities. Consequently, it is preferable for firms to take into consideration the specific conditions of each market, such as cultural differences and marketing infrastructures, by localizing or adapting their marketing programs (O'Donnell \& Jeong, 2000).

One of the critiques of the standardisation argument is about worldwide homogenisation in needs and preferences, being is too simplistic, myopic and contrary 
to marketing concept (Boddewyn et al., 1986; Douglas \& Wind, 1987). The standardisation approach of driving the price of the product down and improving the quality of the product implies a product orientation, rather than a customer and competitor orientation (Douglas \& Wind, 1987). A product orientation is so presbyopic that is likely to result in failure (Laughlin, Norvell, \& Andrus, 1994). The market orientation has become more dominant (Jaworski \& Kohli, 1993; Narver \& Slater, 1990). Firms that are concerned solely product costs can fail to detect the idiosyncratic customer needs and preferences across countries, making them more exposed to competitive attacks in individual foreign markets (Cavusgil \& Zou, 1994).

Culture can have an impact on firms' marketing strategies. For example, firms change their brand names in foreign markets to avoid linguistic problem (Francis et al., 2002). Cross-cultural empirical research has confirmed significant differences in customer characteristics, preferences, and purchasing behaviour among different countries (Diamantopoulos, Schlegelmilch, \& Du Preez, 1995). There is no evidence to suggest that customers are so price conscious that they are prepared to take lower price products rather than products with special features developed for them (Theodosiou \& Katsikeas, 2001).

The rationale for the standardisation approach associated with economies of scale and cost savings has been challenged. One of the arguments is the cost savings not being related to financial performance (Samiee \& Roth, 1992; Walters, 1986). In this view, the cost saved is not justified given the potential loss of sales that is the result of not adapting to local circumstances or even failure to fully exploit them. From the strategic point of view, the adaptation approach can enjoy the benefit of penetrating 
foreign markets by tailoring to local tastes (Cavusgil et al., 1993). Adaptation can also enhance motivation and morale of local managers because they have more say in planning and implementing marketing strategy (Douglas \& Wind, 1987; Quelch \& Hoff, 1986). By using adaptation strategy, firms can augment their capabilities in analysing and understanding foreign markets, monitoring market developments overseas, and quickly responding to changes in customer preferences (Craig \& Douglas, 1996). The underlying principle of adaptation approach is the consideration of the unique characteristics of foreign markets. It is believed beneficial to adapt international marketing strategies that suit local conditions. These local conditions are in the forms of culture, regulations, market infrastructure, income level and competition.

\section{Summary of standardization vs adaptation}

The debate between these two camps is continuous and no solution has been identified. However, a fruitful emerging perspective of the extant literature on standardisation versus adaptation appears to be a contingent approach which is somewhere in between the two streams of thoughts. According to this perspective, the difference between standardisation and adaptation is a matter of degree rather than kind (Theodosiou \& Katsikeas, 2001). The concept of “be global, act local”, which has been widely accepted as a better approach due to cultural differences is an approach of contingency theory. That this school of thought advocates the combination of standardisation and adaptation elevates the issue that international marketing strategies need to be examined on the basis of the characteristics of the domestic and overseas markets. The critical issue then becomes under what 
circumstances international marketing strategies should be adapted and how much adaptation is needed.

From the standardisation versus adaptation literature, there are a number of issues that have not been well covered. The aim of a firm that standardises or adapts its international marketing strategies is to satisfy the needs of its target customers better than competitors. The more it can satisfy the customers' needs, the more likely they can succeed in the overseas market. Thus, the understanding of the characteristics, behaviour, tastes, preferences, and usage patterns of the customers in the host markets is very important, so that appropriate adapted or standardised international marketing strategy can be deployed. However, antecedent factors, related to external environment, that affect the standardisation or adaptation strategy are under researched. Theodosiou and Leonidou (2003), in their study of assessing and integrating the empirical research of standardisation versus adaptation of international marketing strategy, explicitly stated that these antecedent factors were surprisingly the least examined by researchers in the field.

Brand adaptation issue has not been addressed in detail. The extant literature on adaptation discusses issues like changing the packaging, prices, and brand names etc. But these changes do not mean that the firms have changed the market positions, which is a psychological facet, in the overseas markets. Therefore, it is beneficiary to look closer at the role of repositioning concept in the international brand management.

The impacts of firm size on internal and external factors such as commitment and culture respectively have not been examined. The existing literature considers small 
and medium size firms taking on these issues in the same way. It however will be necessary to take a closer look at whether this is true.

We now examine certain issues in more detail, starting with culture, the economy and commitment.

\section{Cultural and economic environment}

A country's culture has been considered as a major environmental characteristic that causes systematic differences in buying behaviour (Steenkamp, 2001). Culture can change people's perceptions, dispositions, and behaviours (Markus \& Kitayama, 1991). Many businesses fail simply because of the negligence of taking cultural differences between countries into account. Pawle (1999) provides a conceptual model of how culture influences brand image, brand relationship and brand positioning. Empirical studies on the impact of linguistic differences on international brand name (Francis et al., 2002) and the cultural interpretation of the brand meaning of McDonald (Eckhardt \& Houston, 2002), have shed light on the importance of culture affecting international branding activities.

International marketers require not only people but also people with money. Therefore, it is necessary to understand the income aspect in the host market to deploy marketing strategy. The income conditions in a host market can influence international marketing strategy in several ways. The demand potential for a particular product is based on the economic conditions and a firm's cost structure is also relied on the income conditions (Theodosiou \& Katsikeas, 2001). The overall level of economic and industrial development of a country determines customers' 
preferences for the products (Jain, 1989). Two countries in different development stages may consider the same product as essential or less necessary respectively (Hill \& Still, 1984). This research proposes to use variables to cover a wide range of cultural aspects and income facet in studying their impacts on international brand repositioning.

\section{International commitment}

Managerial commitment to international marketing plays an important role in international marketing strategy. It recognises the existence of considerable differences in market characteristics between a host market and a home market. In order to succeed in international ventures, it is important that firms understand the overseas market situation and employ appropriate international marketing practices in comparison with those in the domestic market. In developing such a capability, international commitment to international business is important (Katsikeas, Piercy, \& Ioannidis, 1996). Unlike external environmental factors, which are beyond the control of a firm; international commitment is both a behavioral and attitudinal factor at the firm level that can be manipulated by the firm (Evangelista, 1994). The attitudinal component is similar to the cognitive, affective and behavioural elements of attitude toward international business (Aaby \& Slater, 1989), whereas the behavioral aspect refers to the amount of effort and resources associated with international business (Cavusgil \& Zou, 1994; Evangelista, 1994). These two domains of international commitment can have a particularly strong impact on international behaviour and success.

\section{Brand Adaptation}


Brand adaptation refers to the adaptation of the market position and identity of a domestic brand to one that is relevant to the minds of its international customers. The logic of brand adaptation is parallel to that of brand re-positioning which has been long considered as an important branding activity in the domestic situation (Aaker \& Shanby, 1982; DiMingo, 1988; Rise \& Trout, 1981). Positioning can be based on specific attributes or abstract aspects (Pham \& Muthukrishnan, 2002), but is a more holistic concept than just the marketing mix. In other words, brand re-positioning is a different concept to marketing mix adaptation.

International marketers consider adaptation of their brands because of competitive pressures, new channels and changing customer needs. Changing customer needs reiterates the significance of cultural differences between the domestic and international markets. For example, honey is deemed to be a herbal medicine in Korea and China, but in Western countries it is just a spread. International marketers need to consider the degree of difference of consumer characteristics and behaviour in making a positioning decision (Ganesh \& Oakenfull, 1999).

Brand adaptation is different to the concept of adaptation of marketing strategy. They both involve a change of the existing offerings such as product features, packaging, language in an advertising message etc. in foreign markets. However, brand repositioning is a broader term that includes the creation and placement of a desired brand in the minds of target customers. It involves psychological factors and physical factors, while adaptation of marketing strategy emphasises the changes of only marketing mix. In order to maximise the brand performance, changes should be based on the cultural and economic environment of the international market. 


\section{International experience}

Experience refers to the extent to which a firm has been involved in its international operation (Cavusgil \& Zou, 1994; Erramilli, 1991; Klein, Frazier, \& Roth, 1990), and includes experience gained from the operation in a particular country or from the operation in the international environment in general. A lack of market knowledge is an important obstacle to the development of international operations. Limited experiential knowledge of the overseas market can create a perception of uncertainty (Agarwal \& Ramaswami, 1992; Davidson, 1982), and this perception can have an adverse effect on the firm's competitive position in the overseas market. Inexperienced firms have been found to overstate the risks and costs of operating internationally and to understate the returns generated from international operations (Caves, 1982; Davidson, 1980). In contrast, firms with relatively high levels of international business experience tend to perceive less uncertainty in their international ventures and hold a better understanding of export market forces (Madsen, 1989). Firms gain and accumulate foreign market knowledge through operations overseas. Knowledge gained through experience from overseas market creates business opportunities which in turn become a driving force in the internationalisation of the firm (Johanson \& Vahlne, 1990). A firm's cumulative knowledge in learning results in improving its business operations by creating a learning curve effect that reduces average unit cost (Chang, 1996). This lower cost enables a firm to generate more business in the future.

\section{Construct Development}

International commitment 
International commitment describes the extent of the resources made available for the international marketing venture. These resources consist of both finance and human resources. Mavondo and Rodrigo (2001) studied inter-organisational commitment in organisations conducting business between Australia and China. One of their items that is relevant has been chosen for use. This item taps into the intention and determination of the resources for the international venture. In another paper, Cavusgil and Zou (1994) studied the impact of commitment on export performance by using the extent of management commitment to the venture. These two items that represent a broader sense of the extent of management and resource commitment were used together with that from Evangdista (1994) and two new items, making it up to five items, to examine the construct of international commitment.

1. We have promised resources (e.g. information technology \& human resources) to the international ventures (v1)

2. The extent of management commitment to the international marketing venture is substantial (v2)

3. Our firm sets aside adequate funds to develop overseas markets (v3)

4. Our firm's executives travel frequently to foreign markets (v4)

5. International business is a high priority activity in company (v5)

\section{Brand adaptation}

Brand adaptation refers to the changes of the market position and identity of a domestic brand, to suit the overseas market situations. Positioning can be based on attribute specific and/or abstract aspects (Pham \& Muthukrishnan, 2002). Thus, the construct of brand adaptation needs to include both physical and psychological aspects. International marketers consider adaptation of their brands because of 
competitive pressures, new channels and changing customer needs. Changing customer needs reiterates the significance of the cultural differences between the domestic and international markets. International marketers should consider the degree of difference of consumer characteristics and behaviour in making a positioning decision (Ganesh \& Oakenfull, 1999). Adaptation of a brand requires changing the target market and/or the brand image in an international market place or product features. There have been few empirical studies on positioning in international marketing context (Ganesh \& Oakenfull, 1999). With regard to brand positioning, studies have been conducted to find out the criteria of brand positioning (Pham \& Muthukrishnan, 2002; Romaniuk, 2001) and a new technique to enhance brand-positioning strategy (Marsden, 2002). Ganesh and Oakenfull (1999) have used perceptual mapping techniques to study international product positioning based on U.S. and Mexican consumers' perceptions. However, little work on brand adaptation has been done about what repositioning is comprised of. Kalafatis, Tsogas and Blankson (2000) have examined positioning strategies of UK timber trade in business markets in general. Some of the variables used in this proposed study are retrieved from their work as those variables can capture both the physical aspect such as product feature and psychological aspect like target market.

1. Compared to the domestic market, the target market of the brand in the foreign market was changed (v6)

2. Compared to the domestic market, the approach of promotion / advertising in the foreign market was different ( $v 7)$

3. Compared to the domestic market, the product features in the foreign market much were different ( $v 8$ ) 
4. Compared to the domestic market, the distinctive identity of the brand in the foreign market was different (v9)

5. Compared to the domestic market, the distribution of the brand in the foreign market requires a different method of distribution / outlet (v10)

\section{Cultural and economic market environment}

The external marketing environment denotes the differences between domestic and international markets in which an international marketer operates. Diverse markets encompass external marketing environments, comprising elements in the broader society that may affect firms (Hitt, Ireland, \& Hoskisson, 2001; Walters \& Priem, 1999). Firms cannot directly control the elements of the external marketing environment. Those cultural aspects within external marketing environment of the overseas market are likely to be different to those of the domestic market. Literature on external marketing environment focuses heavily on the sources, processes and use of information at the corporate level (Fahey \& King, 1977; Ghoshal, 1988; Hambrick, 1982; Preble, Rau, \& Reichel, 1988; Subramanian, Fernandes, \& Harper, 1993). While the variables used in these studies are centred on economic, customers and competitive areas; the cultural aspects are often untouched. Since there are no suitable items that can be used for the construct, a new construct is developed for this study. The key feature is that each item in the cultural scale is in relative terms, namely the perception of some facet of culture in the foreign market relative to the home market. Thus the scale can be used by research in any home country and applied to any host country, providing the business has experience of both markets, which they do in our study because that is the country all the questions are geared to. 
1. In relation to the domestic market, the customers in this foreign market behave differently (v11)

2. In relation to the domestic market, the motivation of customers in the foreign is harder to understand (v12)

3. In relation to the domestic market, people in this foreign market tend to value individual time more (v13)

4. In relation to the domestic market, interpersonal relationships in this foreign market are more important (v14)

5. In relation to the domestic market, visual aspects such as packaging and colours are more important in this foreign market (v15)

6. In relation to the domestic market, the culture in this foreign market is totally different $(v 16)$

With regard to the income level, this study proposes using disposable income and a general idea of wealth to represent the construct. Disposable income as an economic measure of the amount left after the basic necessities have been acquired can vary from country to country. This measure also takes into consideration cultural differences. For example, most of people in Asia live with their parents until they get married; resulting in all their income earned being disposable. Disposable income is also a better measure than GDP/GNP that do not reflect the buying power of the customers in the host markets.

- In relation to the domestic market, disposable income of this foreign market is lower (v17)[reverse score]

- In relation to the domestic market, the customers in this foreign market are wealthier ( $v 18)$ 
International experience

International experience refers to the necessary knowledge that is acquired through operations overseas. Firms with international experience understand the subtle characteristics of the international markets and are apt to choose the most appropriate market for the venture (Cavusgil et al., 1993; Douglas \& Craig, 1989). The advantages brought about by the international experience result from a firm's cumulative knowledge in learning to improve its marketing operations. In most previous studies simple orl proxies mainly have been used (Li \& Ogunmokun, 2000; Mutinelli \& Piscitello, 1998). In Cavusgil and Zou's (1994) study, six items have been used to portray the international competence. In fact, only three of them are related to international experience of export firms. This study will adopt one of the items to examine the construct of international experience of international firms.

- $\quad$ Number of foreign markets in which your firm operates (v19)

\section{Hypotheses: Relationship between external marketing environment and brand adaptation}

A brand needs to be adapted to respond to the uniqueness and special characteristics of the overseas market. The adaptation issue becomes critical in the international context. In line with domestic marketing, international marketers need to consider the extent of homogeneity in consumer characteristics and behaviour when making a position decision. International marketers also need to be aware of the similarities and differences of the foreign markets on a number of aspects that are not an issue in domestic marketing decision. When the external marketing environment changes, brand offerings should also be altered accordingly. When culture and income are 
different between the host and overseas markets, brand repositioning seems to be warranted. Thus:

Hypothesis 1: Cultural difference between the host and overseas markets is a positive determinant of brand adaptation.

Hypothesis 2: Income difference between the host and overseas markets is a positive determinant of brand adaptation.

\section{Relationship between international commitment and brand adaptation}

Brand adaptation is an expensive and time-consuming exercise. When a firm adapts its brand in an overseas market, it needs resources to support this activity. These resources could be in the form of human resources, money and information technology. A high level of commitment to international business could be from firms’ executives travelling frequently to overseas markets (Evangelista, 1994). When firms consider international business being a high priority activity, marketing activities such as repositioning in the overseas markets will be more highly valued. Thus:

Hypothesis 3: international commitment is a positive determinant of brand adaptation.

\section{Relationship between international experience and brand adaptation}

Buckley and Casson (1985) argue that experience reduces the cost and uncertainty of serving a market and in turn increases the probability of firms committing resources to foreign market. As a result, brand adaptation can be carried out in a more effective and efficient manner. The proposition is that experience with international markets 
increases the likelihood of committing a large amount of resources to branding activities in foreign markets. Thus:

Hypothesis 4: international experience is a positive determinant of brand adaptation

Insert figure 1 here

\section{Methodology \& Data Analysis}

The scope of this study covers micro, small and medium sized firms. Micro firms were defined as having between one and ten staff. Small firms were defined as having between eleven and fifty staff. Medium sized firms were defined as having between fifty-one and four hundred and ninety nine staff. In this study we received 288 usable surveys based on a mail out to Australian firms involved in international business in 2004 . The response rate was $12 \%$ which might seem low but is comparable to many industrial surveys, as stated by Hart (1987). The collected data was inputted in the Statistical Package for the Social Sciences (SPSS) programme for reliability analysis and multiple regression analysis; and in AMOS for confirmatory factor analysis (CFA). As suggested by Armstrong and Overton (1977), a t-test was performed between early and late responses to examine whether non-response bias was a problem. No non-response problem was found. The respondents, not the researchers, chose the foreign market. Respondents were asked to nominate a single country on which the answers to the questions were based. This helped the respondents focus on one particular country. In turn the information given is more pure and able to reflect the truth compared to answering the questions with different countries in mind. 


\section{Constructs and measures}

The scales used for the variables are either interval or ratio scales. The recommendation of numerical scales from 1 to 7 was used to measure variables (Schumacker \& Lomax, 1996). The use of the same scale values for variables assists in the interpretation of results and/or relative comparison of variables in the analysis. For each of the statements, respondents were required to rate on a scale ranging from "strongly disagree or decreased enormously" through "neutral” to "strongly agree or increased enormously”. Cronbach Alpha test was used to examine the reliability, which is an assessment of the degree of consistency between multiple measurements of a construct (Hair, Anderson, Tatham, \& Black, 1998). The coefficient measures of this test with values 0.6 or more indicates satisfactory internal consistency reliability (Carmines \& Zeller, 1979; Robinson, Shaver, \& Wrightsman, 1991). Items below this threshold were taken out from further analysis to ensure reliability of the constructs. Table 1 below summaries the Alpha values before and after deleting the item from the construct.

Insert table 1 here

\section{Confirmatory factor analysis}

\section{Brand adaptation}

The results of the Confirmatory factory analysis indicate an excellent fit, adjusted goodness of fit index $(\mathrm{AGFI})=0.98$. Also, the P-value for the chi-square statistic of 0.412 is good because it is insignificant, indicating a close fit between the model and the data.. Regarding the factor loadings, the standardised coefficients for all the indicators are above 0.55 (0.72, $0.57,0.80,0.77,0.67$ respectively), indicating construct validity. Details of the statistics are shown in figure 2. It can be noted that 
the best two indicators for this construct are "product features” (v8), which has 0.79 factor loading and “distinctive brand identity” (v9), which has 0.77 factor loading.

Insert figure 2 here

\section{Commitment}

The results of CFA in general are very satisfactory after covariating two indicators. All of the most widely used indices achieve excellent results. For instance, the pvalue for Chi-square is greater than 0.05 , and AGFI is greater than 0.90 . The standardised factor loading coefficients $(0.65,0.93,0.82$ 0.84, 0.82) are well above the acceptable level $(0.4$, and the squared multiple correlations for each indicator $(0.42,0.86,0.67,0.70,0.67)$ of this construct are graphically displayed in Figure 3 below. It might be noted that "management commitment" (v2) is perceived to have the strongest impact on this factor with a regression coefficient loading of 0.93 .

Insert figure 3 here

\section{Culture}

After making one covariation, the indices of the goodness of fit tests for culture aspects suggest that the model fits well, with the p-value for chi square statistics being 0.227 and AGFI 0.971. The standardised factor loading coefficients $(0.69,0.62,0.56$, 0.43, 0.70) are well above the acceptable level (0.4), and the squared multiple correlations for each indicator $(0.47,0.38,0.31,0.19,0.48)$ of this construct are depicted in Figure 4 below. The strongest variables in this construct are "culture in the foreign market totally different” (v16) and customers in the foreign market 
behaving differently (v11), with standardised factor loadings of 0.70 and 0.69 respectively.

Insert figure 4 here

\section{Results}

Measures of international commitment, income level, international experience and cultural aspects were entered into a standard multiple regression analysis as predictor variables for brand adaptation. Overall, these four predictors accounted for a significant amount of the variance in brand repositioning $\left(\mathrm{R}=0.47, \mathrm{R}_{\text {adj }}{ }^{2}=0.21\right.$, $\mathrm{F}(4,283)=19.94, \mathrm{p}<0.001)$. Table 2 presents the variables explaining the brand adaptation in order of their importance based on standardised beta coefficient values. The standardised beta estimate coefficient of each variable demonstrates the relative importance of each independent factor variable. A larger estimate represents higher importance of variables in the overall model.

Insert table 2 here

Results revealed that the most influential factor of brand adaptation was culture (beta=0.41, $\mathrm{p}<0.01$ ). In other words, the greater the cultural differences between the host and home country, the more likely international small firms would reposition their brands in the overseas markets $(\mathrm{r}=0.45)$. International commitment came second and was also a very significant predictor of brand adaptation (beta $=0.16$, $\mathrm{p}<0.01$ ). Correlations revealed that firms that are committed to international ventures are more likely to reposition their brands in the overseas market $(r=0.22)$. The cultural influence was about double that of commitment, although both were significant at the one percent level. 
Contrary to culture aspects and international commitment, international experience (beta=-0.068, $\mathrm{p}>0.05$ ) and income level (beta=-0.035, $\mathrm{p}>0.05$ ) did not significantly contribute to international brand adaptation. Our view of the lack of significance for experience is that firms that have a lot of experience, possibly in many markets, have a well-proven formulae for their brand and therefore are very unlikely, ceteris paribus, to want to change it when entering a new market (the context for the current study). Similarly, economic factors may not be important for brand adaptation because only the more affluent middle class segments are targeted. China may have lower per capita incomes than most Western countries, but this may be irrelevant if it is only the comfortable middle and higher income segments that are likely to be buying Western products and services. Countrywide, aggregate statistics commonly used to assess foreign markets might therefore be misleading. Certainly our statistical results support this interpretation, that foreign income levels is not a major consideration in the international brand adaptation decision.

\section{Discussion}

This study provides evidence that both external (culture) and internal (commitment) factors influence small and medium sized firms when they consider international brand adaptation decisions. The study implies a knowledge-based model or framework that could be useful to small and medium size business already involved or considering entering international business. This study contributes to empirical research explaining the antecedents of brand adaptation of SMEs in international marketing. This is significant because our research supports the notion that international commitment and cultural aspects have considerable impact on international brand repositioning. By increasing the commitment in the overseas 
market and the understanding the cultural aspects, SMEs international marketers are more likely to adapt their brands overseas. The adaptation includes not only changing the marketing mix, but also considers psychological aspects like brand identity or market position.

International marketers may want to consider their resources in terms of money and human resources before conducting a brand adaptation exercise. Brand adaptation costs money and the adaptation of the marketing mix needs funds for support. Human specialists in brand repositioning need to be available. Channel members sometimes play a significant role here. Careful examination of understanding the host market's culture is another critical issue for international marketers when considering repositioning their brands. The findings confirm the existing literature that cultural backgrounds of foreign markets significantly impact on international marketing and branding strategy.

Insert table 3 here

A closer examination of the impact of firm size on the determinants of international brand adaptation provides further insight. The standardised coefficients of cultural aspects and international commitment are depicted in table 3. The results show that micro firms (with staff ten or less) are more influenced by resource considerations than their larger counterparts in brand adaptation. It may be due to the fact that micro firms are very constrained by resources and therefore have to be very sure that they are committed before embarking on international brand adaptation. While medium sized firms may have more diverse businesses, the international business may not be critical to them with consequence of committing fewer resources in the international 
business ventures. In contrast to international commitment, cultural aspects are significantly important to almost all irrespective of the firm sizes, except high medium sized firm (with 100 to 499 staff) which is just statistically significant (sig. level 0.06). It demonstrates that almost all firms in different sizes take into consideration cultural aspects when adapting their brands for the target customers in overseas markets. This external factor is a stronger driving force of brand adaptation than an internal factor, international commitment.

Another contribution of this study is the operationalisation of two new constructs, cultural aspects and brand adaptation. The former construct was measured in relative terms, comparing home and host country perceptions. The brand adaptation construct was developed in a holistic manner, that reflects the standardisation / adaptation of a brand in multiple facets that tap into both the marketing mix and the psychological areas of a brand. The items within the construct provide insights for international marketers repositioning their brands overseas.

Further studies are needed to generalize on our results. For micro, small and mediumsized firms, culture seems to be the dominant influence on the international brand adaptation decision. The sample used here covered more than 40 countries so our culture measure would seem to be robust. Moreover, it is based on the statistical confirmatory factor tests. Nonetheless, testing with a different home country (such as USA, UK or Canada), would further support the findings. Commitment of resources as a determinant of international brand adaptation seems to be especially important for micro firms. Micro firms, more so than small or medium sized firms, should be 
cognizant of this resource need before they enter foreign markets, or alternatively,

stick to culturally similar countries where the need to adapt the brand is not as great.

\section{References:}

Aaby, N. E., \& Slater, S. F. (1989). Management influences on export performance: A review of the empirical literature. International Marketing Review, 6(4), 7-26.

Aaker, D. A., \& Shanby, G. (1982). Positioning your product. Business Horizons, 25(3), 56-62.

Agarwal, S., \& Ramaswami, S. (1992). Choice of foreign market entry mode: Impact of ownership, location and internationalization factors. Journal of International Business Studies, 23(3), 1-27.

Armstrong, S. J., \& Overton, T. S. (1977). Estimating nonresponse bias in mail surveys. Journal of Marketing Research, 14(3), 396-402.

Boddewyn, J. J., Soehl, R., \& Picard, J. (1986). Standardization in international marketing: Is Ted Levitt in fact right? Business Horizons, 29(6), 69-75.

Buckley, P. J., \& Casson, M. C. (1985). The economic theory of the multinational enterprise. London: Macmillan.

Carmines, E. G., \& Zeller, R. (1979). Reliability and Valuidity Assessment. Beverly Hills: Sage PUblications.

Caves, R. E. (1982). Multinational entreprises and economic analysis. New York: St. Martin's Press.

Cavusgil, S. T., \& Zou, S. (1994). Marketing strategy-performance relationship: An investigation of the empirical link in export market ventures. Journal of Marketing, 58(1), 1-21.

Cavusgil, S. T., Zou, S., \& Naidu, G. M. (1993). Product and promotion adaptation in export ventures: An empirical investigation. Journal of International Business Studies, 24(3), 479-506.

Chang, T. L. (1996). Cultivating global experience curve advantage on technology and marketing capabilities. International Marketing Review, 13(6), 22-42.

Craig, C. S., \& Douglas, S. P. (1996). Developing strategies for global marekts: An evolutionary perspective. Columbia Journal of World Business, 31(1), 70-81.

Davidson, W. H. (1980). The mode choice and change decision process and its impcact on interntional performance. International Business Review, 2(1), 97120.

Davidson, W. H. (1982). Global Strategic Management. N.Y.: John Wiley and Sons.

Diamantopoulos, A., Schlegelmilch, B. B., \& Du Preez, J. P. (1995). Lessons for PanEuropean Marketing? The role of consumer preferences in fine tuning the product-market fit. International Marketing Review, 12(2), 38-52.

DiMingo, E. (1988). The fine art of positioning. Journal of Business Strategy, 9(2), 34-38.

Douglas, S. P., \& Craig, C. S. (1989). Evolution of global marketing strategy: Scale, scope and synergy. Columbia Journal of World Business, 24(3), 47-58.

Douglas, S. P., \& Wind, Y. (1987). The myth of globalization. Columbia Journal of World Business, 22(4), 19-29.

Eckhardt, G. M., \& Houston, M. J. (2002). Cultural paradoxes reflected in brand meaning: McDonald's in Shanghai, China. Journal of International Marketing, 10(2), 68-82. 
Erramilli, M. K. (1991). The experience factor in foreign market entry behaviour of service firms. Journal of Interntional Business Studies, 22(3), 479-501.

Evangelista, F. U. (1994). Export performance and its determinatns: Some empirical evidence from Australian manufacturing firms. In Advances in International Marketing (Vol. 6, pp. 207-229). Greenwich: JAI Press.

Fahey, L., \& King, W. R. (1977). Environmental scanning for corporate planning. Business Horizons, 20(4), 61-75.

Fisher, A. B. (1984). The ad biz gloms onto global. Fortune, 12 November(61-4).

Francis, J. N. P., Lam, J. P. Y., \& Walls, J. (2002). Executive insights: The impact of linguistic differences on international brand name standardization: A comparison of Enghish and Chinese Brand name of Fourtune-500 Companies. Journal of International Marketing, 10(1), 98-116.

Ganesh, J., \& Oakenfull, G. (1999). International product positioning: An illustration using perceptual mapping techniques. Journal of Global Marketing, 13(2), 85111.

Ghoshal, S. (1988). Environmental scanning in Korean firms: Organizational isomorphism in action. Journal of International Business Studies, 19(1), 6986.

Hair, J. F. J., Anderson, R. E., Tatham, R. L., \& Black, W. C. (1998). Multivariate Data Analysis (5th ed.). Upper Sadde River, J.J.: Prentice Hall.

Hallibuton, C., \& Hunerberg, R. (1993). Executive insight: Pan European marketing Myth or reality? Journal of International Marketing, 1(3), 77-93.

Hambrick, D. C. (1982). Environmental scanning organizational strategy. Strategic Management Journal, 3(2), 159-174.

Hart, S. (1987). The use of the survey in industrial market research. Journal of Marketing Management, 3(1), 25-38.

Hill, J. S., \& Still, R. R. (1984). Adapting products to LDC taste. Harvard Business Review, 62(2), 92-101.

Hitt, M. A., Ireland, R. D., \& Hoskisson, R. E. (2001). Strategic Management: Competitiveness and Globalization (4th ed.). Cincinnati: South-Western College Publishing.

Jain, S. (1989). Standardization of international marketing strategy: Some research hypotheses. Journal of Marketing, 53(1), 70-79.

Jaworski, B. J., \& Kohli, A. K. (1993). Market orientation: Antecedents and consequences. Journal of Marketing, 57(3), 53-70.

Johanson, J., \& Vahlne, J.-E. (1990). The mechanism of internationalization. International Marketing Review, 7(4), 11-24.

Kalafatis, S. P., Tsogas, M. H., \& Blankson, C. (2000). Positioning strategies in business markets. Journal of Business \& Industrial Marketing, 15(6), 416-437.

Katsikeas, C. S., Piercy, N., \& Ioannidis, C. (1996). Determinants of export performance in a European context. European Journal of Marketing, 30(6), 635.

Klein, S., Frazier, G. L., \& Roth, V. J. (1990). A transaction cost analysis model of channel integration in interntional markets. Journal of Marketing Research, 27(May), 196-208.

Laughlin, J. L., Norvell, D. w., \& Andrus, D. M. (1994). Marketing presbyopia. Journal of Marketing Theory and Practice, 2(4), 1-10.

Levitt, T. (1983). The globalization of markets. Harvard Business Review, 61(May/June), 92-102. 
Li, E. L. Y., \& Ogunmokun, G. (2000). The effect of flexibility on export venture performance. Journal of Global Marketing, 14(3), 99-126.

Madsen, T. K. (1989). Successful export marketing management: Some empirical evidence. International Marketing Review, 6(4), 41-57.

Markus, H. R., \& Kitayama, S. (1991). Culture and the self: Implications for cognitio, emotion, and motivation. Psychological Review, 98(2), 224-253.

Marsden, P. (2002). Brand positioning: Meme's the word. Marketing Intelligence and Planning, 20(5), 307-312.

Mavondo, F. T., \& Rodrigo, E. M. (2001). The effect of relationship dimensions on interpersonal and interorganizational commitment in organizations conducting business between Australia and China. Journal of Business Research, 52(2), 111-121.

Mutinelli, M., \& Piscitello, L. (1998). The influence of firm's size and international experience on the ownership structure of Italian FDI in manufacturing. Small Business Economics, 11(1), 43-56.

Narver, J. C., \& Slater, S. (1990). The effect of market orientation on business profitability. Journal of Marketing, 54(October), 20-35.

O'Donnell, S., \& Jeong, I. (2000). Marketing standardization within global industries: An empirical study of performance implications. International Business Review, 17(1), 19-33.

Ohmae, K. (1985). Triad Power: The Coming Shape of Global Competition. New York, NY: The Free Press.

Onkvisit, S., \& Shaw, J. J. (1989). The international dimension of branding: strategic considerations and decisions. International Marketing Review, 6(3), 22-34.

Pawle, J. (1999). Mining the international consumer. Journal of the Market Research Society, 41(1), 19-32.

Pham, M. T., \& Muthukrishnan, A. V. (2002). Search and alignment in judgment revision: Implications for brand positioning. Journal of Marketing Research, 39(1), 18-30.

Preble, J. F., Rau, P. A., \& Reichel, A. (1988). The environmental scanning practicws of U.S. multinationals in the late 1980's. Management International Review, 28(4), 4-14.

Quelch, J. A., \& Hoff, E. J. (1986). Customizing global marketing. Harvard Business Review, 64(May/June).

Rise, A., \& Trout, J. (1981). Positioning: The battle for your mind. New York: McGraw-Hill Inc.

Robinson, J. P., Shaver, P. R., \& Wrightsman, L. S. (1991). Criteria for scale selection and evaluation. In J. P. Robinson, P. R. Shaver \& L. S. Wrightsman (Eds.), Measures of Personality and Social Psychological Attitudes. San Diego, California: Academic Press.

Romaniuk, J. (2001). Brand positioning in financial services: A longitudinal test to find the best brand position. Journal of Financial Services Marketing, 6(2), 111-121.

Rosen, B. N., Boddewyn, J. J., \& Louis, E. A. (1989). U.S. brands abroad: An empirical study of global branding. International Marketing Review, 6(1), 719.

Samiee, S., \& Roth, K. (1992). The Influence of Global Marketing Standardization on Performance. Journal of Marketing, 56(2), 1-17.

Sandler, D. M., \& Shani, D. (1992). Brand globally but advertise locally?: An empirical investigation. International Marketing Review, 9(4), 18-31. 
Schumacker, R. E., \& Lomax, R. G. (1996). A Beginner's Guide to Structural Equation Modeling. Mahwah, N.J.: Erlbaum Associates.

Steenkamp, J. E. M. (2001). The role of national culture in international marketing research. International Marketing Review, 18(1), 30-44.

Still, R. R., \& Hill, J. S. (1984). Adapting consumer products to lesser-developed markets. Journal of Business Research, 12(1), 51-61.

Subramanian, R., Fernandes, N., \& Harper, E. (1993). Environmental scanning in U.S. companies: Their nature and their relationship to performance. Management International Review, 33, 271-286.

Theodosiou, M., \& Katsikeas, C. S. (2001). Factors influencing the degree of international pricing strategy standardization of multinational corporations. Journal of International Marketing, 9(3), 1-18.

Theodosiou, M., \& Leonidou, L. C. (2003). Standardization versus adaptation of international marketing strategy: An integrative assessment of the empirical research. International Business Review, 12(2), 141-171.

Walters, B. A., \& Priem, R. L. (1999). Business strategy and CEO intelligence acquisition. Competitive Intelligence Review, 10(2), 15-22.

Walters, P. G. P. (1986). International marketing policy a discussion of the standardisation consturct and its relevance for corporate policy. Journal of International Business Studies, 17(2), 55-69.

Wind, Y. (1986). The myth of globalization. Journal of Consumer Marketing, 3(2), 23-26.

Wong, H. Y., \& Merrilees, B. (2005). A brand orientation typology for SMEs: A case research approach. Journal of Product and Brand Management, 14(1).

Zou, S., Andrus, D. M., \& Norvell, D. W. (1997). Standardization of international marketing strategy by firms from a developing country. International Marketing Review, 14(2), 107-123.

Zou, S., \& Cavusgil, S. T. (1996). Global strategy: A review and an integrated conceptual framework. European Journal of Marketing, 30(1), 52-69. 
Table 1 Results of a Cronbach's Alpha's reliability test

\begin{tabular}{|l|l|l|l|l|l|}
\hline Dimension & Initial \# of items & Initial Alpha & Items Deleted & Revised \# Items & Revised Alpha \\
\hline Brand adaptation & 6 & 0.83 & n.a. & 6 & 0.83 \\
\hline Culture Aspects & 6 & 0.70 & V13 & 5 & 0.74 \\
\hline International Commitment & 5 & 0.90 & n.a. & 5 & 0.90 \\
\hline International Experience & 1 & n.a. & n.a. & 1 & n.a. \\
\hline Income Level & 2 & 0.79 & n.a. & 2 & 0.79 \\
\hline
\end{tabular}

Table 2 Results of a standard multiple regression analysis

\begin{tabular}{|l|l|c|c|c|c|}
\hline \multirow{2}{*}{ Hypotheses } & \multicolumn{1}{|c|}{ Variables } & $\begin{array}{c}\text { Standardised } \\
\text { beta }\end{array}$ & T-value & Sig & Results \\
\hline H1 & Cultural Aspects & 0.413 & 7.401 & 0.000 & Supported \\
\hline H2 & Income Level & -0.035 & -0.642 & 0.521 & Rejected \\
\hline H3 & International Commitment & 0.155 & 2.670 & 0.008 & Supported \\
\hline H4 & International Experience & -0.068 & -1.181 & 0.239 & Rejected \\
\hline
\end{tabular}


Table 3 Standardised beta values of international commitment and cultural aspects by firm sizes (absolute t-values in brackets)

\begin{tabular}{|c|c|c|c|c|c|}
\hline Dimension & $\begin{array}{l}\text { Firm size - } \\
1 \text { to } 10 \text { staff } \\
(n=99)\end{array}$ & $\begin{array}{l}11 \text { to } 50 \\
\text { staff } \\
(n=112)\end{array}$ & $\begin{array}{l}51 \text { to } 100 \\
\text { staff } \\
(n=37)\end{array}$ & $\begin{array}{l}101-499 \\
\text { staff } \\
(n=40)\end{array}$ & $\begin{array}{l}\text { All cases } \\
(n=288)\end{array}$ \\
\hline $\begin{array}{l}\text { International } \\
\text { commitment }\end{array}$ & $\begin{array}{l}0.325 \\
(3.12)^{* *}\end{array}$ & $\begin{array}{l}0.016 \\
(0.16)\end{array}$ & $\begin{array}{l}0.213 \\
(1.57)\end{array}$ & $\begin{array}{l}-0.014 \\
(0.08)\end{array}$ & $\begin{array}{l}0.155 \\
(2.67)^{* *}\end{array}$ \\
\hline $\begin{array}{l}\text { Cultural } \\
\text { aspects }\end{array}$ & $\begin{array}{l}0.294 \\
(3.05) * *\end{array}$ & $\begin{array}{l}0.490 \\
(5.30)^{* *}\end{array}$ & $\begin{array}{l}0.517 \\
(3.75)^{* *}\end{array}$ & $\begin{array}{l}0.324 \\
(1.97)^{*}\end{array}$ & $\begin{array}{l}0.413 \\
(7.40)^{* *}\end{array}$ \\
\hline
\end{tabular}

* denotes a marginally significant result $\mathrm{p}<0.06$

** denotes a significant result $\mathrm{p}<0.01$ 


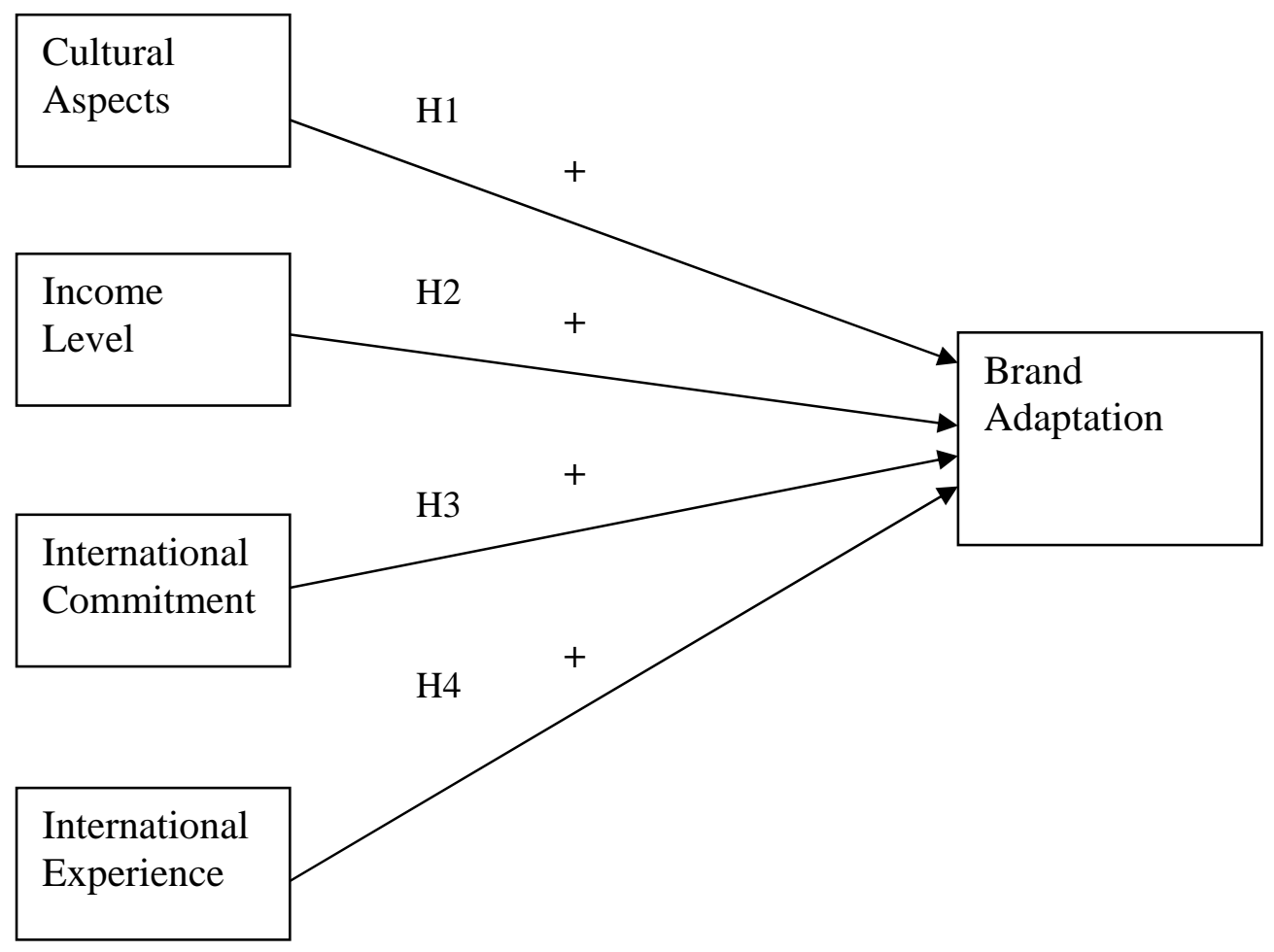

Figure 1: Conceptual Framework For Global Brand Adaptation 


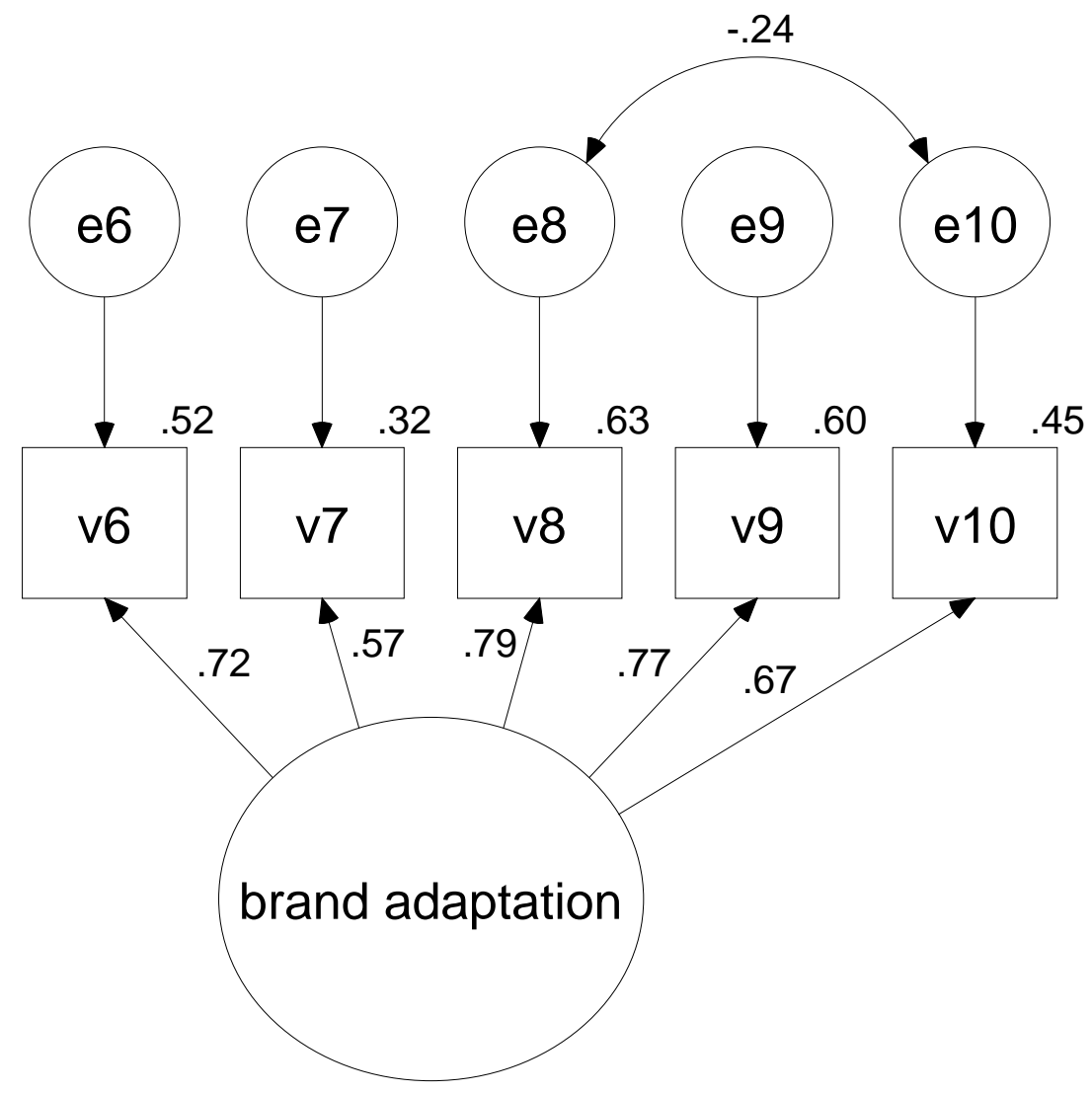

Figure 2 Brand adaptation: Standardised factor loading for the squared multiple correlations. Chi-square $=3.953$ (df 4) $p=0.412$, AGFI=0.980 


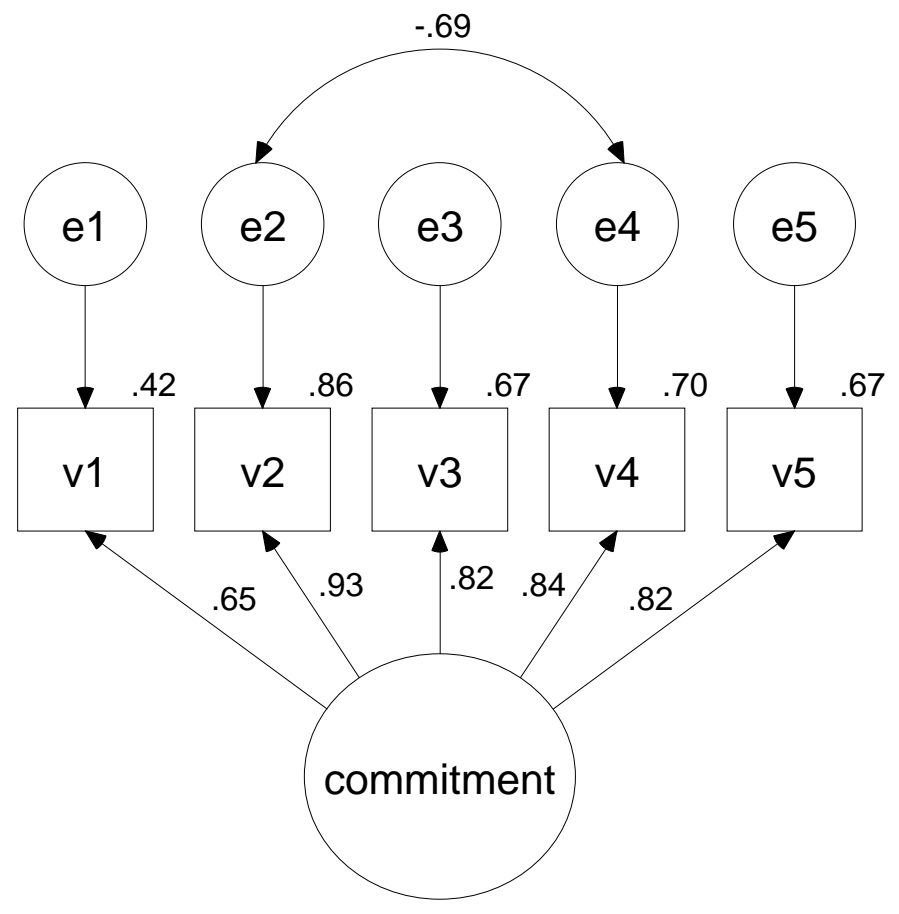

Figure 3 International commitment: Standardised factor loading and the squared multiple correlations. Chi-square $=5.115(\mathrm{df} 4) \mathrm{p}=0.276, \mathrm{AGFI}=0.974$ 


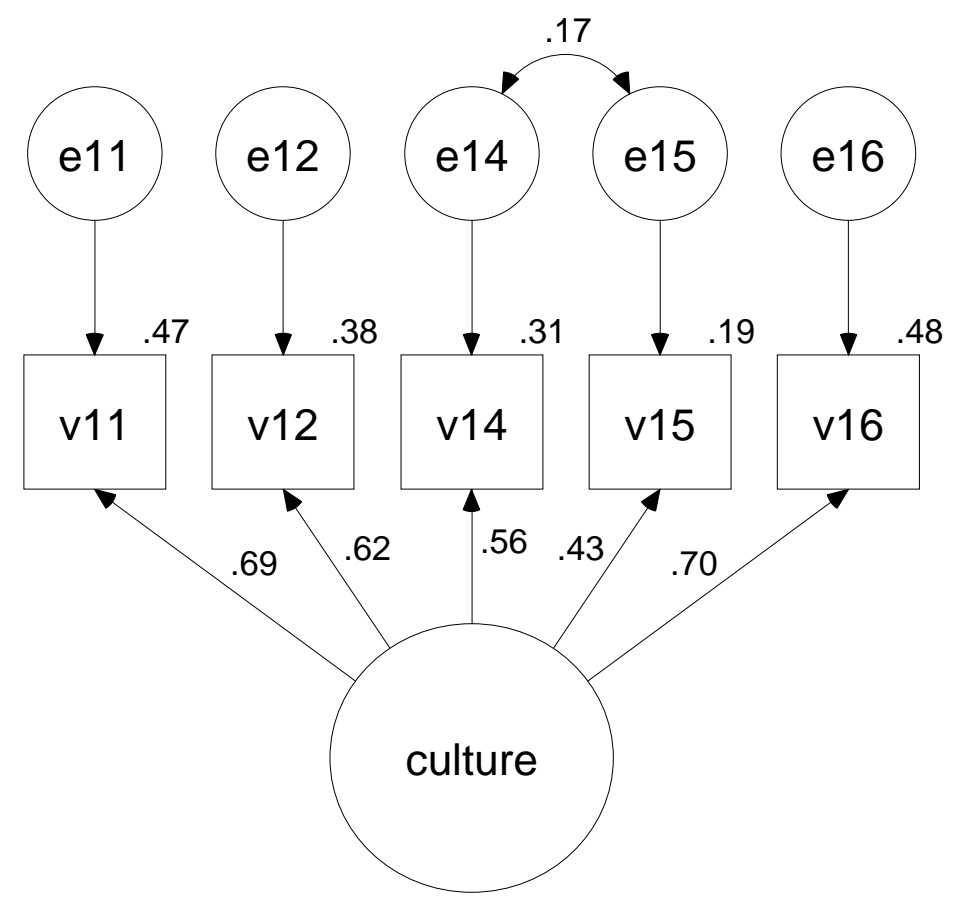

Figure 4 Cultural aspects: Standardised factor loadings and the squared multiple correlations. Chi-square $=5.647(\mathrm{df} 4) \mathrm{p}=0.227$, AGFI $=0.971$ 